\title{
A REVIEW ON POTENTIAL USES OF CULINARY VEGETABLES USED IN ROUTINE LIFE AS AN ANTICANCER AGENT
}

\author{
LAVANYA B, JAYASHREE V*, JEEVARAJ $S$
}

Department of Pharmacology, School of Pharmaceutical Sciences, Vels Institute of Science, Technology and Advanced Sciences, Pallavaram, Chennai - 600 117, Tamil Nadu, India. Email: mailtovjayashree@gmail.com

Received: 24 February 2018, Revised and Accepted: 24 April 2018

\begin{abstract}
Cancer is a disease which leads to death, and chemotherapy is a treatment used to treat cancer. Lung cancer and breast cancer are most effective one in the world. The present study examines the anticancer property of culinary vegetables such as Allium vegetables, cruciferous vegetables, and beetroot which are used in day-to-day life have anticancer properties. Allicin and gallic acid in garlic decreases the risk of colon, pancreas, stomach, esophagus, and breast cancers. In onion, cysteine sulfoxide is sulfur compounds which have ant-cancer, antiplatelet, and antithrombotic property. In broccoli, glucosinolates and sulfur compounds play a major role in the treatment of breast and prostate cancer. Betacyanin is a compound present in beetroot which has antioxidant property and anticancer activity.
\end{abstract}

Keywords: Anticancer, Gallic acid, Cysteine sulfoxide, Glucosinolates, Betacyanin.

(C) 2018 The Authors. Published by Innovare Academic Sciences Pvt Ltd. This is an open access article under the CC BY license (http://creativecommons. org/licenses/by/4. 0/) DOI: http://dx.doi.org/10.22159/ajpcr.2018.v11i8.25457

\section{INTRODUCTION}

Cancer is deadly disease that involves abnormal cell growth and spread to other parts of the body [1]. Cancer is not only one disease but also a group of more than 100 distinct disorders [2]. It is the second leading cause of mortality in the world, and chemotherapy is the main modalities available for cancer treatment. However, recently, chemotherapeutic drugs which are available in the market are reported to exhibit toxicity toward normal tissues and possess undesirable side effects [3]. Cancer influences any race, any age group, or societal class and disseminated all around the world that leads to significant loss of human lives. Statistics indicates that men are mostly suffered from lung, colon, rectum, and prostate cancer, while women increasingly suffer from breast, colon, rectal, and stomach cancer [4]. Two types of tumors are benign tumor (non-cancerous) and malignant tumor (cancerous). Most common type of cancer includes lung cancer, breast cancer, liver cancer, stomach cancer, and colorectal cancer.

Cancers are classified by the tumor cells and are made up of special type of cells. These include carcinoma (tumors derived from the epithelial cells of the body organs), sarcoma (tumors arise from the connective tissue such as bone, cartilages, fat, and nerve), lymphoma/leukemia (tumors arise from blood-forming cells), germ cell tumor (tumors derived from pluripotent cells and germ cells present in the testicle or ovary), and blastoma (tumors derived from the immature precursors cells) [5].

Cancer-fighting vegetables include Allium vegetables (garlic, leeks, and yellow and green onions), cruciferous vegetables (broccoli, brussels sprouts, cauliflower, kale, red cabbage, and curly cabbage), spinach, and beet root also scored in the top ten against many of the cancers tested.

\section{GARLIC (ALLIUM SATIVUM)}

Garlic (A. sativum L.) belongs to family Amaryllidaceae, and it is also called as poor man's treacle. The garlic bulb consists of more than 200 chemical compounds, such as volatile oil with sulfur-containing compounds, namely ajoene (4,5,9-trithiadodeca-1,6,11-triene-9oxide), alliin, and allicin, enzymes, namely peroxidase, alliinase, and myrosinase and other compounds like -phellandrene, - phellandrene, linalool, citral and geraniol are important [6].
Garlic acts as insecticidal, antimicrobial, antiprotozoal, and antitumor activity [7,8]. Epidemiological and experimental studies explain that garlic is a potent vegetable for the prevention of cancer. The anticancer effect of garlic has been reported to exhibit the anticancer effect through their anticarcinogenic, antimutagenic, and antitumor properties by fresh extract, powder, oil of garlic, and several organosulfur compounds derived from garlic. The mechanism of action was found to be inhibition of carcinogen activation, boost phase 2 detoxifying processes, cell cycle arrest of malignant cells mostly in G2/M phases, stimulation of the mitochondrial apoptotic pathway, and an increase of histone acetylation $[9,10]$. The main components of garlic are amino acids (glutaminic acid, arginine, aspartic acid, leucine, lysine, and valine) [11], gallic acid such as polyphenolic compounds, minerals (manganese, potassium, calcium, and phosphorus and in minor quantities: Magnesium, selenium, sodium, iron, zinc, and copper), vitamins (Vitamin B6 and also Vitamin C and in minor quantities, folic acid, panthotenic acid, and niacin), essential oil with many sulphur-containing components (allyldisulfide and allyltrisulfide), Alliin, Ajoene, quercetin, and sugars (fructose and glucose) $[12,13]$. The fibrinolytic activity of garlic in both man and experimental animals has been reported. Many claims have been done on garlic for antibiotic action, hypoglycemic effect, antitumor, antioxidant, and antithrombotic properties [14-17] and have also been attributed to the garlic extracts

\section{Anticancer activity of garlic}

Allicin is one of the most important predecessor of bioactive compounds of garlic. A number of population studies demonstrated a relationship between excess garlic intake and reduction in risks of pancreas, colon, stomach, esophagus, and breast cancers [18]. The organosulfur compounds derived from garlic have been reported to exhibit the anticancer effect through their anticarcinogenic, antimutagenic, and antitumor properties. Recently, studies shown that sativum lectin 50 (ASL50, $50 \mathrm{kDa}$ ) isolated from A. sativum exhibited antiproliferative activity on oral carcinoma KB cells and induces 2.5-fold higher caspase enzyme activity than untreated cells [19].

Anticarcinogenic activity of garlic is also thought to be due to the modulation of carcinogen metabolism. The cell cycle arrest by diallyldisulfides (DADS) in human colorectal tumor cell line, HCT-15, 
has been reported. DADS decreased cells in G1 phase and, in turn, increased cells in G2/M phase [20]. The mechanism of cell cycle arrest by diallyltrisulfides (DATS) at G2/M phase was studied using human prostate cancer cells, PC-3 and DU145 and it was closely associated with reactive oxygen species. The cell cycle arrest by DATS at G2/M phase in prostate cancer cells was associated with reactive oxygen species. The cell cycle arrest with DATS appeared to be selective for cancer cells since a normal prostate epithelial cell line was resistant to cell cycle arrest with DATS [21].

Gallic acid is a polyphenol compound and has been reported for its antiproliferative activity against many cancer cell lines [22]. Prevention of cancer by organosulfur compounds from garlic has been studied in a medium-term bioassay system (Ito assay) to detect liver carcinogens and promoters in rats [23]. In these studies, attention was focused on soluble organosulfur compound chemoprevention in the post-initiation phase of cancer development. In addition, the modifying effects of S-methyl and cysteine on the initiation stage of rat hepatocarcinogenesis were investigated [24].

\section{ONION (ALLIUM CEPA L.)}

The onion is one of the most valuable vegetables. Onions have anticancer properties, antiplatelet activity, antithrombotic activity, and antibiotic effects. These benefits are mainly associated with sulfur compounds called cysteine sulfoxides [25]. The phytochemical research has proved that onion is rich in flavonols and organosulfur compounds, which have exhibited tumor inhibitory properties in laboratory studies [26]. Higher onion intake was decrease the risk of breast cancer. Onion is well known for its benefits to weight control and cancer prevention.

\section{Anticancer activity of onion}

Onions are an important source of several phytonutrients as flavonoids, fructooligosaccharides (FOS), and thiosulfonates and other sulfur compounds [27]. Flavonoids are the major phenolics in onions, and some flavonoids are flavones, flavanones, flavonols, isoflavones, flavanonols, flavanols, chalcones, and anthocyanins [28]. Flavonols are the most abundant in onions, present as their glycosides, i.e., quercetin and kaempferol [29]. The sulfur-containing compounds present in onion are S-alk(en)yl-L-cysteine sulfoxides [30].

The epidemiological studies proved that garlic, onions, and related Allium vegetables was used for the prevention of cancers of gastrointestinal tract such as stomach cancer, colorectal cancer, and to some extent esophageal cancers. Mechanism involves alteration of the biological behavior of tumors, tumor microenvironments, or precancerous cells, and the way it decreases cancer risk [31].

Anticancer and antibacterial activity has been proved in the lactofermented of onion extracts. In some research, a good correlation between the flavonoid contents of onions and cytotoxic or antibacterial activity have been proved, and, hence data demonstrated that lactofermented onions are used against breast cancer cells [32]

\section{BROCCOLI (BRASSICA OLERACEA L.)}

Cruciferous vegetables such as cauliflower and broccoli are the most consumed vegetables [33]. Cruciferous are known to possess antioxidant activity [34]. Bioactive phytochemicals such as glucosinolates, phenolic compounds, Vitamin C, and mineral nutrient are present in broccoli [35]. They play a role in the prevention of chronic diseases, breast, and prostate cancer [36,37].

Broccoli (B. oleracea L.) has been marketed as a health-promoting food because it naturally has high content of bioactive phytochemicals such as glucosinolates, phenolic compounds, Vitamin C, and mineral nutrients. Broccoli has also been found to exhibit antioxidant activity that prevents oxidative stress related to many diseases. Various epidemiologic studies have indicated that consumption of broccoli is associated with a lower risk of cancer, including breast, prostate, lung, stomach, and colon cancers [38-40]. The anticancer effect of broccoli has been attributed to sulforaphane (SFN), an isothiocyanate formed by hydrolysis of a precursor glucosinolate called "glucoraphanin." Although glucoraphanin [41] is found in varying amounts in all cruciferous vegetables, the highest concentration of this compound is found in broccoli and its sprouts [42].

\section{Anticancer effect of broccoli}

SFN suppresses the expression of multidrug resistance protein, reduced drug efflux, and increased anticancer activity. In subcutaneous tumor model of Barrett esophageal adenocarcinoma, a significant decrease in tumor volume was also observed. The anticancer activity was mainly due to the induction of caspase 8 and p21 and down-regulation of hsp90, a molecular chaperone required for the activity of several proliferation-associated proteins. It also shown that bread enriched with broccoli sprouts was found to be effective against stomach cancer [43]. Furthermore, the effect on in vitro proliferation and motility of stomach cancer cells differing in metastatic potential were studied. Thus, these studies indicate that broccoli sprouts may serve as a valuable food supplement preventing upper gastrointestinal system.

\section{BEETROOT (BETA VULGARIS L.)}

Beetroot is a vegetable plant and belongs to family Amaranthaceae. The roots of beet have used in traditional Arab medicine to treat a wide variety of diseases. The claimed therapeutic use of beetroot includes its antitumor, carminative, emmenagogue, and hemostatic and renal protective properties and is a potential herb used in cardiovascular conditions. It consists of chemical compounds such sa betalain, betacyanins, betanin, and betaxanthine. They also have carotenoids, glycine betaine, saponins, betacyanines, betanin, polyphenols, and flavonoids.

Beetroot possesses antihypertensive, hypoglycemic, antioxidant [44], anti-inflammatory, and hepatoprotective activities [45-48].

In beetroot, the betacyanin is a chemical constituent which is responsible for red beet color, and it is an antioxidant with modulator of oxidative stress. Research area is mainly focused on anticancer activities of beetroot extract, and in animal models, has unravelled their potential benefits as chemopreventive and chemotherapeutic agents [49].

\section{Anticancer activity of beetroot}

Treatment of ethanolic extract of beetroot reduced the amount of cleaved caspase 3 and Bax and protein expression and increased the Bcl-2 protein expression [50]. Cyanidin-3-0-glucoside chloride had growth inhibitory activities against the human colon (CACO-2), hepatocellular (HepG2), and breast (MCF-7) carcinoma cell lines, respectively [51].

\section{CONCLUSION}

For centuries, Allium vegetables have been used in a wide variety of cuisines worldwide and are valued for their potential medicinal properties. During the first Olympic Games in Greece, garlic was consumed as a stimulant, and in Roman times, soldiers chewed garlic before battle for strength. At present, these vegetables continue to hold their fascination for their unique flavor, chemistry, and biological properties. Epidemiological studies indicate that consumption of Allium vegetables was protective against cancers, particularly GIT cancer.

Garlic-derived components play major roles to protect cells from the mutation and to prevent the undifferentiated cell growth. Thus, the daily consumption of garlic may contribute to prevent cancer. As onion is rich in flavonols and organosulfur compounds, its higher intake decreases the risk of breast cancer and it is also well-known for its benefits to weight control and cancer prevention. 
Broccoli by-products such as leaves and stems contain high total phenolics, and hence, it shows high antioxidant and anticancer activities. Thus, these by-products can be used as functional food ingredients in the food industry. Beetroot is rich in carotenoids and polyphenols, and it shows good antitumor, carminative, emmenagogue, and hemostatic and renal protective properties.

\section{CONFLICTS OF INTEREST}

No conflict to disclose.

\section{REFERENCES}

1. Cancer Fact sheet N 297. World Health Organization. February; 2014

2. Kundusen S, Gupta M, Mazumder UK, Haldar PK, Saha P, Bala A, et al. Antitumor activity of citrus maxima (Burm.) merr. Leaves in Ehrlich's ascites carcinoma cell-treated mice. ISRN Pharmacol 2011;2011:138737.

3. Jeena K, Liju VB, Kuttan R. Antitumor and cytotoxic activity of ginger essential oil (Zingiber officinale Roscoe). Int J Pharm Pharm Sci 2015;7:341-4.

4. Cragg GM, Newman DJ. Plants as a source of anticancer agents. J Ethnopharmacol 2011;100:72-9.

5. Claudette GV. A Cancer Source Book For Nurses. Boston: Jones and Bartlett Publishers; 2004. p. 229.

6. Bolton S, Null G, Troetel WH. The medicinal uses of garlic-fact or fiction. Am Pharm 1982;22:448-51.

7. Buiatti E, Palli D, Decarli A, Amadori D, Avellini C, Bianchi S, et al. A case-control study of gastric cancer and diet in italy. Int J Cancer 1989;44:611-6.

8. Rode H, de Wet PM, Cywes S. The antimicrobial effect of Allium sativum L. (Garlic). S Afr J Sci 1989;85:462-4.

9. Kim JY, Kwon O. Garlic intake and cancer risk: An analysis using the food and drug administration's evidence-based review system for the scientific evaluation of health claims. Am J Clin Nutr 2009;89:257-64.

10. Iciek M, Kwiecień I, Włodek L. Biological properties of garlic and garlic-derived organosulfur compounds. Environ Mol Mutagen 2009;50:247-65.

11. Ariga T, Seki T. Antithrombotic and anticancer effects of garlic-derived sulfur compounds: A review. Biofactors 2006;26:93-103.

12. Ross SA, Finley JW, Milner JA. Allyl sulfur compounds from garlic modulate aberrant crypt formation. J Nutr 2006;136:852S-854S

13. Bordia A, Joshi HK, Sanadhya YK, Bhu N. Effect of essential oil of garlic on serum fibrinolytic activity in patients with coronary artery disease. Atherosclerosis 1977;28:155-9.

14. Bordia A, Verma SK, Vyas AK, Khabya BL, Rathore AS, Bhu N, et al. Effect of essential oil of onion and garlic on experimental atherosclerosis in rabbits. Atherosclerosis 1977;26:379-86.

15. Adetumbi MA, Lau BH. Allium sativum (garlic) - A natural antibiotic. Med Hypotheses 1983;12:227-37.

16. Mathew PT, Augusti KT. Hypoglycaemic effects of onion, Allium cepa linn. On diabetes mellitus - A preliminary report. Indian J Physiol Pharmacol 1975;19:213-7.

17. Weisberger AS, Pensky J. Tumor inhibiting effects derived from an active principle of garlic (Allium satuvum). Science 1958;126:1112-4.

18. Nema R, Khare S, Pradhan A. Anticancer activity of Allium sativum (Bulb) polyphenolic compound. Int J Pharm Sci Rev Res 2014;29:131-4.

19. Reddy NM, Reddy NR, Jamil K. Spicy anti-cancer spices: A review. Int J Pharm Pharm Sci 2015;7:1-6.

20. Knowles LM, Milner JA. Depressed p34cdc2 kinase activity and G2/M phase arrest induced by diallyldisulfide in HCT-15 cells. Nutr Cancer 1998;30:169-74

21. Xiao D, Herman-Antosiewicz A, Antosiewicz J, Xiao H, Brisson M, Lazo JS, et al. Diallyltrisulfide-induced G2-M phase cell cycle arrest in human prostate cancer cells is caused by reactive oxygen speciesdependent destruction and hyperphosphorylation of Cdc25 C. Oncogene 2005;24:6256-68.

22. Fukushima S, Takada N, Hori T, Wanibuchi H. Cancer prevention by organosulfur compounds from garlic and onion. J Cell Biochem Suppl 1997;27:100-5.

23. Fukushima S, Takada N, Wanibuchi H, Hori T, Min W, Ogawa M. Suppression of chemical carcinogenesis by water-soluble organosulfur compounds. J Nutr 2001;131:1049-53.

24. Samaranayake MD, Wickramasinghe SM, Angunawela P, Jayasekera S, Iwai $\mathrm{S}$, Fukushima $\mathrm{S}$, et al. Inhibition of chemically induced liver carcinogenesis in wistar rats by garlic (Allium sativum). Phytother Res 2000;14:564-7.

25. Starkenmann C, Niclass Y, Troccaz M. Nonvolatile S-alk(en)ylthio-1cysteine derivatives in fresh onion (Allium cepa L. cultivar). J Agric Food Chem 2011;59:9457-65.

26. Pérez-Gregorio MR, Regueiro J, Simal-Gándara J, Rodrigues AS, Almeida DP. Increasing the added-value of onions as a source of antioxidant flavonoids: A critical review. Crit Rev Food Sci Nutr 2014;54:1050-62.

27. Virtanen AL, Matikkala EJ. The isolation of S-methyl- Lcysteinesulphoxide and S-n-propyl-L-cysteine from onion (Allium cepa) and the antibiotic activity of crushed onion. Acta Chem Scand 1976;13:1898-900.

28. Slimestad R, Fossen T, Vågen IM. Onions: A source of unique dietary flavonoids. J Agric Food Chem 2007;55:10067-80.

29. Pérez-Gregorio RM, García-Falcón MS, Simal-Gándara J, Rodrigues AS, Almeida DP. Identification and quantification of flavonoids in traditional cultivars of red and white onions at harvest. J Food Composition Anal 2010;23:592-8.

30. Santas J, Almajano MP, Carbó R. Antimicrobial and antioxidant activity of crude onion (Allium cepa, L.) extracts. Int J Food Sci Technol 2010;45:403-9.

31. Nicastro HL, Ross SA, Milner JA. Garlic and onions: Their cancer prevention properties. Cancer Prev Res (Phila) 2015;8:181-9.

32. Ravanbakhshian R, Behbahani M. Evaluation of anticancer activity of lacto-and natural fermented onion cultivars. Iran J Sci Technol Trans Sci. 2017. DOI: org/10.1007/s40995-017-0348-0.

33. Byers T, Perry G. Dietary carotenes, vitamin C, and vitamin E as protective antioxidants in human cancers. Annu Rev Nutr 1992;12:139-59.

34. Deng GF, Lin X, Xu XR, Gao LL, Xie JF, Li HB, et al. Antioxidant capacities and total phenolic contents of 56 vegetables. J Funct Foods 2012;5:260-6

35. Jeffery EH, Brown AF, Kurilich AC, Keck AS, Matusheski N, Klein BP, et al.Variation in content of bioactive components in broccoli. J Food Compos Anal 2003;16:323-30.

36. Moreno DA, Carvajal M, López-Berenguer C, García-Viguera C. Chemical and biological characterisation of nutraceutical compounds of broccoli. J Pharm Biomed Anal 2006;41:1508-22.

37. Kaur C, Kumar K, Anil D, Kapoor HC. Variations in antioxidant activity in broccoli (Brassica oleracea L.) cultivars. J Food Biochem 2007:3:621-38.

38. Clarke JD, Dashwood RH, Ho E. Multi-targeted prevention of cancer by sulforaphane. Cancer Lett 2008;269:291-304.

39. Ambrosone CB, McCann SE, Freudenheim JL, Marshall JR, Zhang Y, Shields PG. Breast cancer risk in premenopausal women is inversely associated with consumption of broccoli, a source of isothiocyanates, but is not modified by GST genotype. J Nutr 2004;134:1134-8

40. Joseph MA, Moysich KB, Freudenheim JL, Shields PG, Bowman ED, Zhang Y, et al. Cruciferous vegetables, genetic polymorphisms in glutathione S-transferases M1 and T1, and prostate cancer risk. Nutr Cancer 2004:50:206-13

41. Chung FL, Conaway CC, Rao CV, Reddy BS. Chemoprevention of colonic aberrant crypt foci in fischer rats by sulforaphane and phenethyl isothiocyanate. Carcinogenesis 2000;21:2287-91.

42. Gawlik-Dziki U, Świeca M, Dziki D, Sęczyk Ł, Złotek U, Różyło R, et al. Anticancer and antioxidant activity of bread enriched with broccoli sprouts. Biomed Res Int 2014;2014:608053.

43. Zhang Y, Talalay P, Cho CG, Posner GH. A major inducer of ant carcinogenic protective enzymes from broccoli: Isolation and elucidation of structure. Proc Natl Acad Sci 1992;89:2399-403.

44. Winkler BW, Schroecksnadel K, Schennach H, Fuchs D. In vitro effects of beet root juice on stimulated and unstimulated peripheral blood mononuclear cells. Am J Biochem Biotechnol 2005;1:180-5.

45. Ninfali P, Angelino D. Nutritional and functional potential of Beta vulgaris cicla and rubra. Fitoterapia 2013;89:188-99.

46. Singh A, Garg VK, Sharma PK, Gupta S. Wound healing activity of ethanolic extract of Beta vulgaris. Pharmacol Online 2015;1:1031-38.

47. Jain SG, Sharma Pk. Anti-inflammatory activity of aqueous extract of Beta vulgaris L. J Basic Clin Pharm 2011;2:83-6.

48. Chakole R, Zade S, Charde M. Antioxidant and anti-inflammatory activity of ethanolic extract of Beta vulgaris Linn. roots. Int J Biomed Adv Res 2011;2:124-30

49. De Zwart FJ, Slow S, Payne RJ, Lever M, George PM, Gerrard JA, et al. Glycine betaine and glycine betaine analogues in common foods. 
Food Chem 2003;83:197-204

50. Atamanova A, Brezhneva TA, Slivkin AI, Nikolaevskii VA, Selemenev VF, Mironenko NV. Isolation of saponins from table beetroot and primary evaluation of their pharmacological activity. Pharm Chem J
2005;39:650-2.

51. Chen M, Meng H, Zhao Y, Chen F, Yu S. Antioxidant and in vitro anticancer activities of phenolics isolated from sugar beet molasses. BMC Complementary Altern Med 2015;15:13. 